4. Thesenpapier der Bertelsmann Stiftung auf der Basis der Interkulturellen-Kompetenz-Modelle von Dr. Darla K. Deardorff. - Bertelsmann Stiftung, 2006. - 44 S. // www.bertelsmann-stiftung.de

5. Зимняя И.А. Ключевые компетенции - новая парадигма результата образования // Педагогика. 2003. № 3. C. 34-42.

6. www.bundestag.de/bundestag/aufgaben/rechtsgrundlagen/grundgesetz/index

7. www.constitution.ru

\title{
Lugovskoy A.V. \\ New Standards of Russian Higher Education: Towards Reformation or Reformulation?
}

doi: 10.18411/lj-11-2018-28

idsp: ljournal-11-2018-28

\section{Abstract}

The article deals with the problem of standardisation in Russian higher education. It is particularly focused on the implementation of standards of two generations in the field of linguistics. The article compares the two generations of standards and argues that the ongoing reform, though changing the surface documental side of the issue, does not serve as an effective means for educational quality improvement.

Keywords: Higher education. standardisation, standards, quality of education.

\section{Introduction}

Over the past two decades the system of higher education (HE) in Russia has undergone a fundamental change consisting in the transition from the traditional to a new educational model. The change was underpinned by a set of reforms caused by both internal and external processes. Among the internal factors was the ineffectiveness of the previous five-year "specialist" degree system. The main reason for that was the discrepancy between that degree and its foreign equivalents. The second reason was the increase in the number of public institutions, which resulted in commercialising education and discrediting its academic value. The external factors included the challenges and trends that world education had, such as diversification, individualisation, informatisation, standardisation, and others. Reforming the system thus aimed to unify various aspects at the national and international levels and determine criteria for educational effectiveness and quality.

According to Russian Ministry of Education and Science, quality of education (including ) in the new reality in ensured through three major criteria: Licencing, State Accreditation and State educational standards Licencing provides an institution with the right to carry out educational activity according to a list of criteria. Accreditation is the assessment of the higher educational institution which allows one to issue state recognized diplomas. State educational standards are a series of guidelines which "set out requirements for learning outcomes, structure of curricula, and conditions of their implementation in educational institutions" (Ministry of education, 2017).

This article will look at the state national standards for the area "Linguistics (Baccalaureate)". Two generations of standards will be compared and discussed in terms of their educational quality and improvement potential.

\section{The concepts of quality and standards in education}

When it comes to conceptualising quality and standards in education, particularly in $\mathrm{HE}$, a researcher is inevitably faced with many questions. Among those are To what degree are these concepts related? Does setting high standards result in achieving high quality? etc. In order to answer these questions, one has to look closely into the concepts of standards and quality and single out those characteristics which make it possible to compare or contrast the two notions.

The traditional approach to standards and quality is stated in the proposition that quality is conceptualized in terms of meeting the set standards. Quality here is viewed as "conformance to a specification or standard" (Green, 1994, p.13). In other words, the quality is measured by the conformity of the final product to the designed model. This can 
specifically apply to manufacturing industry where final products are to follow a set of criteria. This idea is well expressed in R. Barnett's (1992) work:

The standard of an enterprise is the measure or criterion (or set of criteria) against which the enterprise is to be judged. It is the performance of the enterprise against the standards in question that determines whether the enterprise is of high quality or not. (p. 55)

This approach has always taken place in education. Government initiatives (National curricular, Teacher's Standards, HE Professional Standards, etc.) in providing education with certain criteria of performance determine those desired results that public bodies consider as educational quality. Sammons (2007) states, that "raising standards of achievement is seen as fundamental to sustaining economic performance" (p. 5). Setting standards makes certain stakeholders believe that outcomes of the educational process can be measured in terms of their correspondence to key criteria, "yardsticks" (Green, 1994, p. 13) and thus fit into being "qualitative."

However, applying standards to education does not necessarily guarantee the quality of educational performance even if these standards are met. The problem consists in the fact that standards and quality are sometimes viewed as conceptually different phenomena. The concept of standards "is essentially quantitative” as Bartholomew (2000, p. 121) argues. Standards can be measured in terms of level achievement. In contrast, quality does not necessarily have measurement characteristics. Besides, quality will not be guaranteed by the standards in operation but learning aspiration of students and high professionalism of their teachers (Barnett, 1992, pp. 57-58).

In my opinion, both approaches have the right to exist. The underlying problem here is not the discrepancy between the concepts of standards and quality but the essence of quality itself. The answer to the dilemma is possible only when one defines what they mean by educational quality and whose perspective they take.

Quality can be considered in relativist terms and conceptualized as "fitness for purpose.” The relativism of this approach is determined by the character of the purpose, in other words, who sets the purpose and is interested in the results. In HE there are different stakeholders (the government, academics, school leaders, consumers (students, parents), and others) whose vision of educational purpose can be different.

Some researchers (Peter de Vries, 1997, p. 51; Barnett, 1992, p.31) argue that the quality of education in general and HE in particular should be examined through its benefits to students whose achievements must be the corner stone for assessing its quality. These achievements may not be measured quantitively. In this respect quality or worthwhile education, as R. Aldrich (2000) claims,

is about the promotion of knowledge over ignorance, of truth over falsehood, of concern for others over selfishness, of effort over sloth, of mental and physical well-being over despair and debility. If we neglect these truths in order to put a spin or gloss upon education for other purposes - whether we are politicians, journalists, authors, academics, teachers - then we shall be agents in lowering rather than raising educational standards. (p. 55)

\section{Background and Critique of Russian HE Standards}

Until now, Russian education has been shaped by three generations of educational standards. They have been underpinned by various legislative acts and initiatives outlining the educational reality at the national and international levels. The first domestic document to define education was Law on Education of 1992 (Government of Russia, 1992). It was the first time the notion of educational standards had been introduced in the modern Russia. Standards were defined as a "set of requirements" imposed on education at its different levels including HE (ibid.). The latter was also legislated in Law on Higher and Professional Education of 1996 (Government of Russia, 1996). Both laws underwent various amendments before 2012 when a unified Federal Law on Education in the Russian Federation (Government of Russia, 2012) was adopted .

The international influence on Russian educational legislative acts came from the Bologna declaration (1996) as well as a number of official documents signed within the 
activity of different European organizations (the ESU, the EUA, the ENQA). One of the most influential documents has been The Standards and guidelines for quality assurance in the European Higher Education Area (ENQA, 2009), a report which sets standards and guidelines for both internal and external quality assurance in HE within the network of the countries-participants.

As a result of the two-level influence Russia developed a set of educational standards for all levels. The first and the second set (or generation) of standards for HE were introduced in early 2000s and were known as State Educational Standards. Later, starting from 2009, there were developed standards for all areas of HE referred to as Federal State Educational Standards (FGOS).

A summary of the objectives of the standards as presented in some works (Senashenko, 2008; Korovin, 2011) shows that the standards are supposed to:

- provide financial assurance of the educational process (through partial governmental budgeting of HE institutions);

- set requirements for educational outcomes;

- restructure educational programmes (via the division of courses into compulsory (basic) and optional (variable) parts);

- extend "academic freedoms" of HE institutions (independence in forming the variable part of the curriculum);

- adapt graduates to labour market and career opportunities.

Some theorists recognize the need for developing such standards in Russian HE (Bolotov\&Efremova, 2007; Aleksankov et al., 2016; Kuzmenko et al., 2006). The proponents of this idea would agree that this will allow the Russian HE system to operate in accordance to international standards and thus assimilate into a broader academic community and labour market (Bolotov\&Efremova, 2007, pp. 7-8).

On the other hand, the introduction of standards has received a large influx of criticism. On a broader scale, critics accuse the standards of being too vague (Pospelov, 2011, p. 6), or incomplete (Aleksankov et al., 2016, p. 14), or incohesive (Senashenko, 2006, p. 14). When analysed more scrupulously, the standards come under stronger criticism. For example, in his article Senashenko (2008, pp. 12-19) discusses main disadvantages of the standards, among which are the following:

- the rejection of the traditional educational model comprising "specialties", "specialisations" and "qualifications";

- superficiality of learning;

- the destruction of the system of academic values and a shift to market values;

- the decrease of research intensity.

The criticism of standards provoked a serious discussion in the Russian academic and educational community. Scientists and officials are working on different solutions to improve the educational system where new approaches could come in harmony with the best traditions and practices which have proved their effectiveness and accountability.

\section{Description of subject matter and critical analysis}

The process of standardisation within the filed of linguistics comprises the period between 2000 and 2018 within which a few generations of standards were introduced. The first generation of standards for linguistics (1GSs) appeared in 2000, preceding the Bologna process of 2003, and it took a few more years for institutions to start introducing new baccalaureate programmes. In 2010 they adopted a second generation standard (2GS) which was altered into a third generation standard (3GS) in 2014 with a few more amendments to follow.

A comparative analysis of the two versions of standards for linguistics, that of 2000 and that of 2014, makes it possible to point out a few similarities. Both documents are similarly structured and include a number of common components, such as Characteristics of the programme, Requirements for programme implementation and outcomes, and Requirements for final academic assessment. 
Both standards emphasize that the area of study includes linguistic education and cross-cultural communication as its core subjects. Besides, there are similarities in the time frames of the programme and its modes of study. The bachelor's programme in linguistics takes four years and has both full-time and part-time modes.

Requirements for programme implementation refer to the characteristics of the teaching stuff, material resources, and internship. For example, both documents lay stress on qualifications and degrees of faculty members. Also, they put emphasis on students' access to library resources, information databases and facilities. Concerning fieldwork, the standards differentiate between educational and on-the-job internship and give general recommendations on its organization.

Regarding final academic assessment, the programme in both standards includes preparation and defence of a graduation thesis (graduation qualification work (VKR)). Besides that, it also mentions exams, although in the newer document they are regarded as optional.

Even though the standards follow some common patterns and trends, they both possess certain differentiating characteristics. One of the most vivid differences in the two standards refers to the programme structure and content. The 1GS divides the content into the federal component, national-regional (university) component, elective and optional components, whereas the 3GS includes a compulsory (basic) component and a variable-based one. The latter component is formed within the institution and comprises about $50 \%$ of the whole educational content. To compare, the national-regional component of the 1GS implied $40 \%$ of variable courses. Another distinctive feature with regard to the programme contents is that the previous document listed concrete disciplines in their connection to the components, while the later standard does not particularize the curriculum but views it in terms of modules and credits. Each credit corresponds to 36 academic hours, that is 18 lectures or seminars, 1.5 hour each. The whole four-year programme covers 240 credits.

Another striking difference consists in the expectations of students' outcomes. The 1GS uses a traditional knowledge-skill approach. It means that a university graduate is supposed to acquire certain knowledge and various attainments and skills which allow them to carry out professional activity in the trained area. The 3GS considers a student's outcomes in terms of competences. The competences are divided into general culture competences, general professional competences, and professional competences.

Besides, the newer standard prescribes the use of modern and innovative educational approaches and methods such as activity approach, project-based learning, the use of information technology, distant learning, and others.A considerable emphasis is put on the use of e-libraries, the development of information-educational environment and inclusive education.

At first sight, the innovations and concepts behind the later draft of the standard may sound like panacea from the problems that Russian education, particularly linguistic education, faces now. But things are easier said than done. On closer examination, the document still has some inconsistencies and speculations, which may question the whole issue.

Take, for example the notion of "competencies" which replaces the traditional "skills" notion. The introduction of this term into the standards brings up at least two questions: How can one guarantee that teaching a certain class results in developing certain competencies in a person? How can we measure or assess those competencies? It is more obvious when it comes to developing professional competencies like "to have theoretical ground" or "to be able to use methodology of pre-translational analysis" (Ministry of Education, 2014, pp. 1011). But in the general cultural competencies part the text says that a graduate is set "to realize the importance of humanistic values for preservation and development of modern civilization" or "to demonstrate the ability and urge to strive for the development of the society on the principles of humanism, freedom and democracy" (Ministry of Education, 2014, pp. 10-11). One may argue that they have to come to an agreement on what is implied in the proclaimed principles in the first turn. And besides, if these competencies stand for 
educational quality, how can it be measured. Or we shall have to admit that there is something behind quality that cannot be viewed in quantitative terms.

Another important issue arises from the title of the standard itself. This is a standard of higher education as compared to the previous standard of higher professional education. However trivial the difference may seem, it has however met considerable criticism. The main opponents of the general $\mathrm{HE}$ model argue that this may lead to a discrepancy between education and labour market and thus make the purpose of HE quite vague (Senashenko, 2008, pp. 13-14). If it is not "hard skills" that we should develop, how can one having a degree in engineering or medicine complete hard tasks? In our case it may result in a wave of university graduates with minimal theoretical and practical background who will have to perform as school teachers or interpreters. Schools might have to set a threshold: the graduates may work at primary or secondary school without going onto a higher level. This again will lead to certain difficulty since in Russia there is a lack of English teachers all over the country, especially in rural areas.

One more problem that may result from the introduced standard has some cultural implications and can lead to negative outcomes as well. It is well known that the Western model of education has a long history and deep-rooted cultural and democratic traditions, where academic and learning styles are based on equality and independence. In contrast, Russian education is more vertically contextualised and relies a lot on authoritative styles in management and leadership as well as learning. It means that some challenges of today's global education (e.g. reduction of classroom instruction, managing diverse contexts) may not be perceived and managed properly both by educators and students. Many of them still require direct instruction and ready-to-use ways. As a result, both are likely to resort to familiar teaching and learning styles and strategies.

\section{Limitations and recommendations}

It is always hard work to make assumptions about any theoretical construct having little practical evidence. This paper made an attempt to discuss and analyse the existing educational standards as applied to a certain educational level and degree (Bachelor in linguistics). It may not be the case in other programmes. Another limitation is that it is quite hard to make judgement about educational quality because of its complex character and different approaches to it.

Besides, research in this area may be characterised by a certain degree of ambiguity caused by the insufficiency of the initial data, i.e. the texts of the standards. When choosing standards as one of the quality criteria, reformers are to be more precise in defining the constituents of the standards and their measurability. For example, they could conceptualise competencies in more detail and outline criteria for their assessment. Otherwise, it may remain just vague speculation.

\section{Conclusion}

No innovation or initiative is implemented within a short period of time. It always takes a while to study the study the changes, advantages and disadvantages in order to make conclusions and modify the existing approaches and methods. Education being a social phenomenon has even more responses to change than anything else.

The process of standardization as part of a broader educational reform launched in Russia at the beginning of the 2000s testifies that there are still many disputable areas and problems. Educators do not agree on both the conceptual and practical levels of standards implementation, which is partly caused by the vagueness and incompleteness of the standards projects. Instead of real practical guidelines they resemble the wordplay of the previous records.

Linguistic education in Russian universities is undergoing transformation as any other educational area. The analysis of the two standards showed that although there are similarities between them, they still possess a number of differences. The changes in the contents may result in positive outcomes, which will be evident with time. But up to now they have remained theoretical constructs in the point concerning their quality results, the latter being undermined by the real educational situation and academic tradition. 
1. Aldrich, R. (2000). Educational Standards in Historical perspective. In H. Goldstein \& A. Heath (Eds.), Educational Standards (pp. 39-56 ). New York: Oxford University Press.

2. Aleksankov, A.M., Mager, V.E., Chernenkaia, L.V., \&Chernenkii, A.V. (2016). Quality Assurance of High Education. OtkrytoeObrazovanie, Vol. 20, Issue. 4, 10-16. (In Russ.)

3. Barnett, R. (1992). Improving higher education: total quality care. Buckingham: Society for Research into Higher Education \& Open University Press.

4. Bartholomew, D.J. (2000). The Measurement of Standards. In H. Goldstein \& A. Heath (Eds.), Educational Standards (pp. 121-138 ). New York: Oxford University Press.

5. Bologna Declaration. (1999). Retrieved October 20, 2018, from http://www.magnacharta.org/resources/files/BOLOGNA_DECLARATION.pdf

6. Bolotov, V.A., \&Efremova, N.F. (2007). The System for Evaluating the Quality of Russian Education. Russian Education \& Society, Vol. 49, Issue 1, 6-23.

7. Green, D. (1994). What is quality in higher education? Concepts, Policy and Practice. In D.M. Green (Ed.), What is Quality in Higher Education (pp. 3-27). Bury St Edmunds: St Edmundsbury Press.

8. Government of Russia (1992). Zakonobobrazovanii [Law on Education]. Retrieved October 19, 2018 from http://www.consultant.ru/document/cons_doc_LAW_1888/

9. Government of Russia (1996). Federalniyzakon o vyisshem i poslevuzovskomprofessionalnomobrazovanii [Federal Law on Higher and Post-Tertiary Vocational Education]. Retrieved October 19, 2018 from http://pravo.gov.ru/proxy/ips/?docbody=\&nd=102043095

10. Government of Russia (2012) Federalnyiyzakonobobrazovanii v rossiyskoyfederatsii [Federal Law on Education in Russian Federation]. Retrieved October 22, 2018 from http://www.consultant.ru/document/cons_doc_LAW_140174/

11. Korovin, V.M. (2011) Osobennostirazrabotkiobrazovatelnyihprogramm, osnovannyihnafederalnyihgosudarstvennyihobrazovatelnyihstandartahtretegopokoleniya. Vestnik VGU, Issue 1, 5-13. (In Russ.)

12. Kuzmenko, N.E., Lunin, V.V., \&Ryzhova, O.N. (2006). On the Modernization of Education in Russia. Russian Education and Society, Vol. 48, Issue 5, 5-22.

13. Ministry of Education (2000). Gosudarstvennyiyobrazovatelnyiystandartvyisshegoprofessionalnogoobrazovaniya. Napravlenie 520500 Lingvistika. Stepen - BakalavrLigvistiki [State educational standard of higher professional education. Pathway: Linguistics 520500. Baccalaureate] Retrieved October 25, 2018 from http://www.consultant.ru/cons/cgi/online.cgi?req=doc\&base=EXP\&n=341958\#036891024081935786

14. Ministry of Education (2014). PrikazMinobrnaukiRossiiot 7 avgusta 2014 g. $\quad$ \# 940 «Ob utverzhdeniifederalnogogosudarstvennogostandartavyisshegoobrazovaniyaponapravleniyupodgotovki 45.03.02 Lingvistika (urovenbakalavriata)» [Order of the Russian Federation Education Ministry of 07.08.2014 on Enactment of the federal state educational standard in the field Linguistics (baccalaureate)] [PDF file]. Retrieved October 25, 2018 from минобрнауки.рф/документы/7539

15. Ministry of education (2017). Russian education system. Retrieved October 18, 2018 from http://www.russianenic.ru/english/rus/

16. Motova, G., \&Pykkö, R. (2012). Russian Higher Education and European Standards of Quality Assurance. European Journal of Education, Vol. 47, Issue 1, 25-36.

17. Pospelov, A.S., Kal'nei, S.G., \&Oleinik, T. A. (2011). The Third-Generation Educational Standards: The View from the Higher Educational Institution. Russian Education \& Society, Vol. 53, Issue 4, 3-22 [PDF file]. Retrieved October 20, 2018 from http://www.tandfonline.com/doi/abs/10.2753/RES1060-9393530401

18. Sammons, P. (2007) School Effectiveness and Equity: Making Connections. A Review of School Effectiveness and Improvement Research - its Implications for Practitioners and Policy Makers [PDF file]. Retrieved October 21, 2018 from https://www.educationdevelopmenttrust.com/ /media/cfbtcorporate/files/research/2007/rschool-effectiveness-and-equity-full-2007.pdf

19. Senashenko, V.S. (2006). Higher Education and the Bologna Transformations. Russian Education \& Society, Vol. 48, Issue 10, 5-15 [PDF file]. Retrieved October 19, 2018 from http://www.tandfonline.com/doi/abs/10.2753/RES1060-9393481001

20. Senashenko, V.S.

kontseptual'nykhosnovakhfederal'nykhgosudarstvennykhobrazovatel'nykhstandartovvysshegoprofessional'no goobrazovaniia. Alma Mater (VestnikVyssheiShkoly), Issue 9, pp. 11-19 (In Russ.)

21. ENQA (2009). [PDF file] Retrieved October 21, 2018 from http://www.enqa.eu/wpcontent/uploads/2015/09/ESG_3edition.pdf

22. Vries, P. de. (1997). Academic Standards and the Quality Management Debate in British Higher Education. In J. Radford, K. Raaheim, R. Williams \& P. de Vries (Eds.), Quantity and Quality in Higher Education (pp. 5163). London, Bristol: Jessica Kingsley Publishers. 